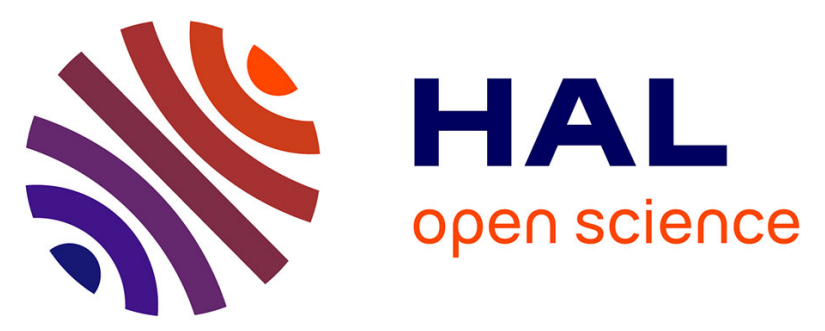

\title{
Comparison of in silico prediction and experimental assessment of ABCB4 variants identified in patients with biliary diseases
}

Boudour Khabou, Anne-Marie Durand-Schneider, Jean-Louis Delaunay, Tounsia Aït-Slimane, Véronique Barbu, Faiza Fakhfakh, Chantal Housset, Michèle Maurice

\section{To cite this version:}

Boudour Khabou, Anne-Marie Durand-Schneider, Jean-Louis Delaunay, Tounsia Ait-Slimane, Véronique Barbu, et al.. Comparison of in silico prediction and experimental assessment of ABCB4 variants identified in patients with biliary diseases. International Journal of Biochemistry and Cell Biology, 2017, 10.1016/j.biocel.2017.05.028 . hal-01535643

\section{HAL Id: hal-01535643 https://hal.sorbonne-universite.fr/hal-01535643}

Submitted on 9 Jun 2017

HAL is a multi-disciplinary open access archive for the deposit and dissemination of scientific research documents, whether they are published or not. The documents may come from teaching and research institutions in France or abroad, or from public or private research centers.
L'archive ouverte pluridisciplinaire HAL, est destinée au dépôt et à la diffusion de documents scientifiques de niveau recherche, publiés ou non, émanant des établissements d'enseignement et de recherche français ou étrangers, des laboratoires publics ou privés. 


\section{Comparison of in silico prediction and experimental assessment of ABCB4 variants identified in patients with biliary diseases}

Boudour Khabou ${ }^{\mathrm{a}, \mathrm{b}}$, Anne-Marie Durand-Schneider ${ }^{\mathrm{a}}$, Jean-Louis Delaunay ${ }^{\mathrm{a}}$, Tounsia AïtSlimane $^{\mathrm{a}}$, Véronique Barbu ${ }^{\mathrm{a}, \mathrm{c}}$, Faiza Fakhfakh ${ }^{\mathrm{d}}$, Chantal Housset ${ }^{\mathrm{a}, \mathrm{c}}$ and Michèle Maurice ${ }^{\mathrm{a}}$

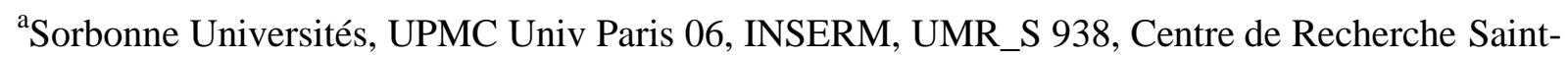
Antoine, F-75012, Paris, France

${ }^{\mathrm{b}}$ Laboratoire de Génétique Moléculaire Humaine, Faculté de Médecine, Université de Sfax, Tunisie

${ }^{c}$ Assistance Publique-Hôpitaux de Paris, Hôpital Saint-Antoine, Centre de Référence Maladies Rares, Maladies Inflammatoires des Voies Biliaires, F-75012, Paris, France

${ }^{\mathrm{d}}$ Laboratoire de Génétique Moléculaire et Fonctionnelle, Faculté des Sciences de Sfax, Université de Sfax, Tunisie

Correspondence: Chantal Housset, UMR_S 938 INSERM/UPMC, CR Saint-Antoine, Faculté de Médecine Pierre et Marie Curie, 27 rue Chaligny, 75571 Paris cedex 12, France

E-mail: chantal.housset@inserm.fr

Phone: +33 1-40-01-13-59

Fax: +33 1-40-01-14-32

Abbreviations: ATP, Adenosine triphosphate; ABC, ATP-binding cassette; ICP, intrahepatic cholestasis of pregnancy; LPAC, low phospholipid-associated cholelithiasis; NBD, nucleotidebinding domain; PFIC3, progressive familial intrahepatic cholestasis type 3.

Financial support: This work was supported by grants from Sorbonne Universités (ProgrammeConvergence@ SorbonneUniversites, Investissements d'avenir) and the association Mucoviscidose-ABCF2. BK received fellowships from the Tunisian government. 


\section{Abstract}

Genetic variations of the phosphatidylcholine transporter, ABCB4 cause several biliary diseases. The large number of reported variations makes it difficult to foresee a comprehensive study of each variation. To appreciate the reliability of in silico prediction programs, 1) we confronted them with the assessment in cell models of two ABCB4 variations (E528D and P1161S) identified in patients with low phospholipid-associated cholelithiasis (LPAC); 2) we extended the confrontation to 19 variations that we had previously characterized in cellulo. Four programs (Provean, Polyphen-2, PhD-SNP and MutPred) were used to predict the degree of pathogenicity. The E528D and P1161S variants were studied in transfected HEK293 and HepG2 cells by immunofluorescence, immunoblotting and measurement of phosphatidylcholine secretion. All prediction tools qualified the P1161S variation as deleterious, but provided conflicting results for E528D. In cell models, both mutants were expressed and localized as the wild type but their activity was significantly reduced, by 48\% (P1161S) and 33\% (E528D). These functional defects best correlated with MutPred predictions. MutPred program also proved the most accurate to predict the pathogenicity of the 19 ABCB4 variants that we previously characterized in cell models, and the most sensitive to predict the pathogenicity of 65 additional mutations of the Human Gene Mutation Database. These results confirm the pathogenicity of E528D and P1161S variations and suggest that even a moderate decrease (by less than 50\%) of phosphatidylcholine secretion can cause LPAC syndrome. They highlight the reliability of in silico prediction tools, most notably MutPred, as a first approach to predict the pathogenicity of $\mathrm{ABCB} 4$ variants.

Keywords: cholestasis, ABC transporter, MDR3, genetic disease, MutPred prediction 


\section{Introduction}

ABCB4, also called MDR3 (multidrug resistance 3) is a lipid floppase, specialized in the secretion of phosphatidylcholine at the canalicular membrane of hepatocytes (Smit et al., 1993). ABCB4 belongs to the ATP-binding cassette (ABC) superfamily of transporters. The molecule is organized in two repeats, each containing a transmembrane domain with six transmembrane helices, and a cytoplasmic nucleotide-binding domain (NBD) (Kast et al., 1995). The transmembrane domains are involved in the specificity towards the substrate and its translocation, whereas NBDs, which are highly conserved among all $\mathrm{ABC}$ transporters, provide the energy for the process (Zolnerciks et al., 2011). NBDs contain several conserved sequences, notably the Walker A and B motifs found in ATPases, and the signature motif, which is a specificity of $\mathrm{ABC}$ transporters (Zolnerciks et al., 2011).

Variations in the $A B C B 4$ gene have been identified as the cause of several hepatobiliary diseases (Gonzales et al., 2009). The most severe of these diseases is progressive familial intrahepatic cholestasis type 3 (PFIC3), a rare autosomal recessive disease occurring early in childhood that may be lethal in the absence of liver transplantation (Jacquemin et al., 2001). Less severe are the low phospholipid-associated cholelithiasis (LPAC) syndrome and intrahepatic cholestasis of pregnancy (ICP), which occur in the young adult. The LPAC syndrome is a biliary gallstone disease characterized by intrahepatic stones and symptomatic cholelithiasis (Rosmorduc et al., 2001), whereas ICP is a reversible cholestatic condition, which occurs in the third trimester of pregnancy and resolves quickly after delivery (Geenes and Williamson, 2009).

A growing number of $A B C B 4$ disease-causing variations has been reported (Jacquemin et al., 2001; Degiorgio et al., 2007; Poupon et al., 2010a, 2013; ABCM database, http://abcmutations.hegelab.org; Human Gene Mutation Database, http://www.hgmd.cf.ac.uk). Most often, the studies were restricted to the mutational screening of the $A B C B 4$ gene and did not address the functional consequences of the variations. Nonsense mutations or mutations leading to a change in the reading frame will certainly result 
in a loss-of-function. However, the pathophysiological consequence of missense mutations often remains uncertain. Several studies have been performed to elucidate the effect of missense variations found in PFIC3 patients, on the structure, trafficking and function of ABCB4 (Delaunay et al., 2009, 2016, 2017; Degiorgio et al., 2014; Gautherot et al., 2012; Gordo-Gilart et al., 2015, 2016). Fewer studies have addressed the effect of missense variations associated with the LPAC syndrome or ICP (Andress et al., 2014; Gautherot et al., 2014). The large number of variants identified by genome sequencing is poorly compatible with exhaustive functional analyses. A number of bioinformatic programs have been developed as a surrogate. These tools are based on different features (Thusberg and Vihinen, 2009) including the physicochemical and structural properties of amino acid residues ( $\mathrm{Ng}$ and Henikoff, 2006) or the evolutionary conservation (Kumar et al., 2014). The relevance of these tools to predict the degree of damaging of a given substitution of ABCB4 has never been explored.

In the current study, we combined in silico approaches and experimental investigations based on cellular models to elucidate the impact of two ABCB4 variations, E528D and P1161S that were previously identified in patients with LPAC syndrome or ICP (Rosmorduc et al., 2003). We then extended the confrontation to nineteen additional variations that we previously experimentally characterized, and to 65 other missense mutations of the Human Gene Mutation Database. 


\section{Patients and Methods}

\subsection{Patients' data analyses}

$A B C B 4$ gene analysis was performed in patients referred to the Reference Center for Inflammatory Biliary Diseases (Hôpital Saint-Antoine, Paris, France), upon informed consent from the patients and approval by the local ethical committee. The 27 coding exons of the ABCB4 gene were amplified together with their exon/intron boundaries from genomic DNA and sequencing was performed on an ABI 3130 Genetic Analyzer (Applied Biosystems-Life Technologies, Saint-Aubin, France), as previously reported (Rosmorduc et al., 2003; Ziol et al., 2008). Gene variations were assessed by sequence comparisons with the SeqScape Software (version 2.5; Applied Biosystems-Life Technologies).

\subsection{In silico analyses}

The evolutionary conservation of E528 and P1161 was estimated using the Clustal Omega program, by alignment of the $\mathrm{ABCB} 4$ protein sequences of different species obtained from the NCBI database (http://www.ebi.ac.uk/Tools/msa/clustalo/). Possible topological change was analyzed via the Protter software (Omasits et al., 2014), a web-based tool which provides an integrated visual analysis of membrane proteins. The degree of pathogenicity of the two mutations was predicted using four in silico programs based on different approaches. Provean (Choi and Chan, 2015) bases its predictions on sequence conservation. A score measures the impact of an amino acid variation based on the amino acid residue at the position of interest and on the quality of sequence alignment derived from the neighborhood flanking sequences. PhD-SNP (Capriotti et al, 2006) is a prediction method based on support vector machines. It classifies a missense variant as pathogenic or neutral, based on the nature of the substitution and the properties of the neighboring sequence environment. Poly-Phen2 (Adzhubei et al., 2013) calculates the probability for a mutation to be damaging using eight sequence-based and three structure-based predictive features of the property of the wild type allele and the corresponding property of the mutant. MutPred (Li et al., 2009) estimates the impact of an amino-acid substitution using a large panel of attributes related to predicted protein structure 
and dynamics, predicted functional properties, amino acid sequence and evolutionary information. The extent of this predicted impact is supplied in terms of probability of deleterious effect. A probability $>50 \%$ is considered as pathogenic (http://mutpred1.mutdb.org/about.html).

\subsection{Homology modeling of $A B C B 4$}

Three dimensional modeling of ABCB4 protein structure was performed using the RaptorX web server as a resource for template-based tertiary structure modeling (Källberg et al., 2014). The wt ABCB4 sequence and the mutated sequences were individually submitted to this server to generate the $3 \mathrm{D}$ models, based on the template $4 \mathrm{f} 4 \mathrm{cA}$ structure of the Caenorhabditis elegans Multi-Drug Transporter, selected as the best template. The quality of models was judged as high based on the Ramachandan plot which showed that $90 \%$ of residues are situated in a favorable area. Then, the Swiss-PDB Viewer software (V4.1) was used to visualize and to compare the generated models (Guex and Peitsch, 1997). The superposition of the two compared models ensures the calculation of the RMSD deviation, which measures the average distance between the backbone atoms of wt and mutated models. A high RMSD deviation indicates that the structural rearrangements caused by the substitution are important (Carugo and Pongor, 2001).

\subsection{Mutagenesis, cells and transfection}

The E528D and P1161S mutations were introduced into the ABCB4 cDNA cloned into the pcDNA3 vector (Delaunay et al., 2009), using the Quik-Change II XL mutagenesis kit from Agilent Technologies (Massy, France). DNA primers used for ABCB4 mutagenesis were from Eurogentec (Angers, France). The sequences were GACACCCTGGTTGGAGACAGAGGGGCCCAGCTGAGTGG (forward) and CCACTCAGCTGGGCGCCTCTGTCTCCAACCAGGGTGTC (reverse) for the E528D mutation and CATCGAGACGTTATCCCACAAATATGAAACAAGAGTGG (forward) and CCACTCTTGTTTCATATTTGTGGGATAAGCTCTCGATG (reverse) for the P1161S mutation. All constructs were verified by automated sequencing. HEK293 cells and HepG2 
cells were transiently transfected with the plasmids using Turbofect (Fermentas France, Villebon-sur-Yvette), as previously described (Delaunay et al., 2016).

\subsection{Immunofluorescence and immunoblotting}

Indirect immunofluorescence was performed on cells grown on glass coverslips after fixation with methanol at $-20^{\circ} \mathrm{C}$, as described (Delaunay et al., 2009). In the case of HEK293 cells, coverslips were pre-coated with poly-L-lysine (Sigma-Aldrich, Saint-Quentin Fallavier, France). The monoclonal P3II-26 anti-ABCB4 was obtained from Enzo Life Sciences (Villeurbanne, France) and Alexa Fluor-labeled secondary antibodies were from InvitrogenLife Technologies. Electrophoresis and immunoblotting were performed as described (Delaunay et al., 2009) using the monoclonal P3II-26 anti-ABCB4 antibody, and peroxidaseconjugated secondary antibodies from Rockland Immunochemicals (Gilbertsville, PA).

\subsection{Measurement of Phosphatidylcholine Secretion}

Phosphatidylcholine secretion was measured in the culture medium of HEK293 cells, as described (Delaunay et al., 2016, Gautherot et al., 2014). Briefly, cells grown in 6-well plates were transfected with the plasmids encoding wt or mutant ABCB4. Sixteen hours posttransfection, the medium was replaced by phenol red-free DMEM containing $0.5 \mathrm{mmole} / \mathrm{L}$ sodium taurocholate and $0.02 \%$ fatty acid-free bovine serum albumin (Sigma-Aldrich). After 24 hours, the medium was collected and lipids were extracted by chloroform/methanol/water partition. The organic phase was evaporated and resuspended in phosphate-buffered saline with $0.1 \%$ Triton X-100 (w/v). Measurement of phosphatidylcholine content was based on the amount of choline released after phospholipase D treatment, using a fluorimetric assay. Results were normalized to the expression levels of wt ABCB4 or of the mutants, which were quantified from immunoblots of the corresponding cell lysates. The Student's $t$ test was used for statistical analysis. 


\section{Results}

\subsection{Patients and mutations}

Two variations were investigated here for the first time: c. $1584 \mathrm{G}>\mathrm{C}$, which causes the amino acid change E528D, and c.3481C>T, which causes the change P1161S. These variations were previously reported with a heterozygous status in four (E528D) and two (P1161S) patients diagnosed with LPAC syndrome (Rosmorduc et al., 2001; Poupon et al., 2013). Patients' sequencing data obtained between 2010 and 2014 in our center, identified the c.1584G $>$ C (E528D) variation in three additional patients diagnosed with LPAC syndrome. Patients' data are presented in Table 1. All patients were heterozygous for the variations. Three patients with the E528D variation were also homozygous or heterozygous for the benign variant R652G (Table 1).

\subsection{In Silico predictions}

The variations studied are located in the first NBD (E528D) and second NBD (P1161S), a few amino acid upstream the ABC signature motif LSGGQ, which is crucial for ATP binding. The sequence alignment of ABCB4 from different species found in the NCBI database (Fig. $1 \mathrm{~A}$ ) showed that the proline at position 1161 is highly conserved. On the other hand, the glutamic acid at position 528 is conserved in primates and several animal species, but others displayed an aspartic acid at this position (Fig. 1 A).

The effect of the E528D and P1161S variations was examined by in silico tools. According to Protter (Omasits et al., 2014), these changes did not affect the overall organization of ABCB4 domains in the membrane. The pathogenicity prediction of these mutations by different programs is shown in Table 2. All programs predicted that P1161S would be deleterious, but they gave discordant predictions for E528D. Provean, which is based on homology information and PolyPhen-2, which refers to evolutionary and structural perspectives estimated that E528D was a neutral substitution. On the other hand, PhD-SNP and MutPred, which take into account structural and functional properties predicted that both E528D and P1161S were deleterious. 
The effect of the two variations was also studied at the structural level by homology modeling of wt ABCB4 and of the mutants. First, the overall structural effect was estimated by the calculation of the root mean square deviation (RMSD) and showed that the mutation P1161S leads to a greater deviation in the structure $(\mathrm{RMSD}=8.51 \AA$ ) than the E528D mutation, which causes minor structural modifications ( $\mathrm{RMSD}=3.56 \AA$ ). Then, we modeled two regions of the molecule, one encompassing amino acids 526-539 and the other one encompassing amino acids 1159-1181, in order to include the sequence LSGGQ of the signature, which is involved in ATP binding in each NBD. The E528D variation led to the addition of a new hydrogen bond within the signature motif between S534 and Q537 (Fig. 1 B). The mutated residue S1161 shared a new hydrogen bond with its neighbor residue H1162 due to the presence of a hydroxyl functional group in the side chain of the serine. This new link replaced the hydrogen connection between D1170 and K1171, which disappeared after replacement of the proline by a serine (Fig. $1 \mathrm{C}$ ).

Taken together, the in silico analyses suggested that the E528D variation would bring moderate changes to the ABCB4 molecule while P1161S would be more deleterious.

\subsection{Expression of the E528D and P1161S ABCB4 mutants in cell models}

Computational results were confronted with those of experimental investigations performed in cell models. Plasmids encoding wt ABCB4 or ABCB4 mutants were transfected in HepG2 and HEK293 cells. The localization of both mutants, indicated by immunofluorescence, was similar to the wt. In HepG2 cells which polarize in culture, wt ABCB4 and the mutants localized at the membrane of bile canaliculi (Fig. 2 A). In HEK293 cells, which do not polarize, all constructs were essentially detected over the whole plasma membrane (Fig. 2 B). By immunoblotting, the pattern of migration of the mutants was similar to that of the wt protein (Fig. 2 C). All three recombinant proteins migrated under a major form corresponding to the fully glycosylated molecule and a minor immature form, as previouly described (Gautherot et al., 2014). These results indicated that the mutations did not affect the maturation process of $\mathrm{ABCB} 4$ or its targeting to the plasma membrane. 
Then, we examined whether the phosphatidylcholine secretion activity of ABCB4 mutants was impaired. Phosphatidylcholine secretion was measured in the culture medium of transiently transfected HEK293 cells as previously described (Gautherot et al., 2014). The amount of phosphatidylcholine released over 24 hours was corrected for the level of the mature protein expressed in the corresponding cell culture well. Then the ratio of phosphatidylcholine released between the mutant and wt transporters was calculated. Cells transfected with the E528D or P1161S mutants released respectively 33\% and 48\% less phosphatidylcholine than the wt protein (Fig. 3). These results show that both mutations caused a defect in phosphatidylcholine secretion, which was moderate in the case of the E528D mutant and more pronounced for the P1161S mutant.

\subsection{Correlation between in silico prediction and experimental analysis of ABCB4 variations}

The results presented above showed that MutPred was the best tool to predict the pathogenicity of two $A B C B 4$ variants found in LPAC patients, especially to predict the mild pathogenicity of the E528D variant. We extended the comparison of in silico vs in cellulo data to all the variants previously studied in our laboratory (Gautherot et al. 2014; Delaunay et al., 2016, 2017). Table 3 shows that MutPred predictions closely correlated with the biological effects that we previously demonstrated. The highest probability of a damaging effect (>90\%) was attributed to seven variations including the I541F and L556R variations, which are trafficking-defective variations and have been shown to cause the most severe phenotype in patients (Delaunay et al., 2016), and the G535D, G536R, S1076C, S1176L, and G1178S variation that affect amino acids directly involved in ABCB4 activity (Delaunay et al., 2017). All four programs agreed on the deleterious effect of these latter variations. Eleven other variations with MutPred scores ranging from 52 to $88 \%$ were not all recognized as deleterious by the three other programs. Finally, the MutPred score of three variations was below $50 \%$. This was the case of the $\mathrm{R} 652 \mathrm{G}$ variation (23\%), previously established as benign, and to the T175A variation (42\%), which caused no apparent defect in cell models. In spite of the apparent safety of these variants, they were predicted to be pathogenic by certain programs (Table 3). The only contradiction to MutPred prediction was the T34M variation 
which was given a low score $(30 \%)$, although it has been shown to cause activity defect (Gautherot et al., 2014). This variation was also recognized as benign by all other prediction programs. This discrepancy may be linked to the particular effect of the T34M mutation on ABCB4 phosphorylation (Gautherot et al, 2014) that may not be well taken into account by prediction tools. Table 4 scores the accuracy of the predictions given by the four programs. The prediction of MutPred was in accordance with results obtained in cell models in 20 cases out of 21, whereas all other programs were less performant.

3.6. Confrontation of MutPred, PhD-SNP, Polyphen2 and Provean to predict the pathogeniciy of disease-associated ABCB4 variants

In order to further investigate the capacity of MutPred to accurately predict the pathogenicity of $\mathrm{ABCB} 4$ variants, we confronted the prediction of the four programs for 65 additional missense mutations reported in the Human Gene Mutation Database (http://www.hgmd.cf.ac.uk). Although reported as disease-associated, most of these mutations have not been characterized in cell models. Results are detailed in Table 5. MutPred predicted that all mutations would be pathogenic, except the G384R mutation considered as pathogenic by all other programs, and the T667I mutation, also predicted as benign by the other programs. A summary is presented in Table 6 . Only $80 \%$ of the mutations were predicted to be pathogenic by PhD-SNP, and $83 \%$ by Polyphen 2 and Provean, when the predictions of MutPred were 97\%. 


\section{Discussion}

In this study, we analyzed the effect of two missense variations in the $A B C B 4$ gene that were identified in LPAC patients, both by using in silico prediction tools and by expressing the mutants in cell models. We show that these variations decreased ABCB4 phosphatidylcholine transport activity, and thus can be considered as responsible for the disease. The P1161S mutation decreased phosphatidylcholine secretion to lower level than the E528D, in accordance with MutPred predictions. The high performance of this program was confirmed with previously characterized ABCB4 variants.

The two variations, E528D and P1161S are located in the NBDs near the ABC signature motif, in well-conserved regions. Studies in cell models showed that these amino acid changes did not affect the processing or targeting of the mutants to the plasma membrane, but reduced the phosphatidylcholine secretion activity. A previous report has shown that two variations located in strategic NBD motifs (L481R and Y403H) also reduced phosphatidylcholine efflux without affecting ABCB4 expression (Degiorgio et al., 2014). Recently, we reported that variations that affect amino acids directly involved in ATP binding within the ABC signature (G535D and G536R in the first NBD, or S1076C, S1176L and G1178S in the second NBD), have a dramatic effect on ABCB4 function (Delaunay et al., 2017). The E528D and P1161S variations are not directly involved in linking ATP, but they may influence its binding or hydrolysis. Indeed, modeling of these regions showed changes in the number and position of hydrogen bonds at the level of the $\mathrm{ABC}$ signature motif. Since hydrogen bonds are engaged in maintaining the appropriate folding needed for function, their reorganization is expected to cause activity defect. The E528D mutation induced little changes at the structural level, and accordingly ABCB4 activity was only slightly decreased. The P1161S mutation caused more changes in the ABCB4 structure, and also affected ABCB4 activity more severely.

The E528D and P1161S variations were first identified with a mono allelic status, in patients diagnosed with LPAC syndrome (Rosmorduc et al., 2003). The E528D variation has also been reported in patients with ICP (Pauli-Magnus et al., 2004; Floreani et al., 2006). Our 
finding regarding the fact that the E528D and P1161S variations affect the phosphatidylcholine secretion activity of $\mathrm{ABCB} 4$ can explain the pathogenic phenotype. It must be noted that the decrease observed in the case of the E528D mutant was only $33 \%$, so that the decrease of total ABCB4 activity in heterozygous patients would be less than $17 \%$ presumably. This result suggests that even a moderate defect in ABCB4 function may at least partly contribute to cholestatic symptoms. However, we cannot exclude that other genetic or epigenetic factors in patients with minor ABCB4 defect, may contribute to the occurrence of the disease. Additional parameters, in particular the hormonal status may play a role. It has already been noted that the LPAC syndrome is more prevalent in female patients and frequently associated with ICP (Poupon et al., 2013). The balance diet or the nature of the bile salt pool may also play a role. $A b c b 4$ knock-out mice are more severely injured when fed cholic acid, the major bile acid in humans, and are almost unaffected when fed ursodeoxycholic acid (van Nieuwkerk et al., 1996). It is interesting to note that certain animal species can tolerate an aspartic acid at position 528 (Fig. 1 A). This is the case of the mouse and the rat, in which the major bile acid is muricholic acid, and ursidae in which the major bile acid is ursodeoxycholic acid, two relatively hydrophilic bile acids.

The bioinformatics investigation was performed in our study in order to assess the value of tools that have been developed to predict whether non-synonymous variants would be neutral or disease-causing. Four computational tools based on different criteria were used to take advantage of their potential complementarity. All four programs predicted that the P1161S variation would be disease-causing whereas they yielded discordant results for the E528D. These discrepancies can be explained in part by the fact that the performance of the prediction may be affected in the case of acidic residues (Thusberg et al., 2011), and probably also because the E528D variation was not very deleterious. The prediction, which best fitted with our studies in cell models was given by MutPred, which attributed a probability of $52.2 \%$ for E528D and of $88.2 \%$ for P1161S indicative of a moderate and a more severe defect, respectively. MutPred takes into account a large panel of attributes related to protein structure, function and evolution, whereas other programs are based on less parameters. The 
MutPred program has already been recognized as one of the best effective methods for the assessment of the effect of missense variants (Frousios et al., 2013). The accuracy of MutPred to predict the pathogenicity of $\mathrm{ABCB} 4$ missense variations is attested by the good correlation with the biological effect of the twenty-one ABCB4 variants analyzed in our laboratory, compared with other programs (Table 4). Furthermore MutPred predicted that $97 \%$ of the mutations reported in the Human Mutation Database would be pathogenic when the other programs predicted only $80-83 \%$, suggesting that it is more sensitive (Table 6).

\section{Conclusion}

In conclusion, our results show that the E528D mutation has mild effect while the P1161S is more damaging, and that among four different in silico tools the prediction of MutPred best fitted these results. MutPred most accurately predicted the pathogenic or benign character of previously characterized $\mathrm{ABCB} 4$ variants in good agreement with the experimental data. MutPred was also the most sensitive in the prediction of the pathogenicity of a large cohort of variations reported in databases. We therefore suggest that MutPred may be chosen as a first computational approach to predict the degree of pathogenicity of ABCB4 variants. 


\section{Acknowledgements}

We thank Romain Morichon (UPMC \& INSERM, UMS 30 LUMIC) for confocal microscopy imaging. 


\section{References}

Adzhubei, I., Jordan, D.M., Sunyaev, S.R., 2013. Predicting Functional Effect of Human Missense Mutations Using PolyPhen-2. Curr. Protoc. Hum. Genet. Chapiter 7, Unit 7-20.

Andress, E.J., Nicolaou, M., Romero, M.R., Naik, S., Dixon, P.H., Williamson, C., Linton, K.J., 2014. Molecular mechanistic explanation for the spectrum of cholestatic disease caused by the S320F variant of ABCB4. Hepatology 59 (5), 1921-1931.

Bacq, Y., Gendrot, C., Perrotin, F., Lefrou, L., Chrétien, S., Vie-Buret, V., Brechot, M.C., Andres, C.R., 2009. ABCB4 gene mutations and single-nucleotide polymorphisms in women with intrahepatic cholestasis of pregnancy. J. Med. Genet. 46 (10): 711-715.

Capriotti, E., Calabrese, R., Casadio, R., 2006. Predicting the insurgence of human genetic diseases associated to single point protein mutations with support vector machines and evolutionary information. Bioinformatics 22 (22), 2729-2734.

Carugo, O., Pongor, S., 2001. A normalized root-mean-square distance for comparing protein three-dimensional structures. Protein Sci. 10 (7), 1470-1473.

Choi, Y., Chan, A.P., 2015. PROVEAN web server: a tool to predict the functional effect of amino acid substitutions and indels. Bioinformatics 31 (16), 2745-2747.

Colombo, C., Vajro, P., Degiorgio, D., Coviello, D.A., Costantino, L., Tornillo, L., Motta, V., Consonni, D., Maggiore, G., SIGENP Study Group for Genetic Cholestasis, 2011. Clinical features and genotype-phenotype correlations in children with progressive familial intrahepatic cholestasis type 3 related to ABCB4 mutations. J. Pediatr. Gastroenterol. Nutr. $52(1), 73-83$.

Degiorgio, D., Colombo, C., Seia, M., Porcaro, L;, Costantino, L., Zazzeron, L., Bordo, D., Coviello, D.A., 2007. Molecular characterization and structural implications of 25 new ABCB4 mutations in progressive familial intrahepatic cholestasis type3 (PFIC3). Eur. J. Hum. Genet. 15 (12), 1230-1238.

Degiorgio, D., Corsetto, P.A., Rizzo, A.M., Colombo, C., Seia, M., Costantino, L., Montorfano, G., Tomaiuolo, R., Bordo, D., Sansanelli, S., Li, M;, Tavian, D., Rastaldi, M.P., Coviello, D.A., 2014. Two ABCB4 point mutations of strategic NBD-motifs do not prevent protein targeting to the plasma membrane but promote MDR3 dysfunction. Eur. J. Hum. Genet. 22 (5), 633-639.

Delaunay, J.L., Durand-Schneider, A.M., Delautier, D., Rada, A., Gautherot, J., Jacquemin, E., Aït-Slimane, T., Maurice, M., 2009. A missense mutation in ABCB4 gene involved in progressive familial intrahepatic cholestasis type 3 leads to a folding defect that can be rescued by low temperature. Hepatology 49 (4), 1218-1227.

Delaunay, J.L., Durand-Schneider, A.M., Dossier C., Falguières, T., Gautherot, J., DavitSpraul, A., Aït-Slimane, T., Housset, C., Jacquemin, E., Maurice, M., 2016. A functional classification of ABCB4 variations causing progressive familial intrahepatic cholestasis type 3. Hepatology 63 (5), 1620-1631.

Delaunay, J.L., Bruneau, A., Hoffmann, B., Durand-Schneider, A.M., Barbu, V., Jacquemin, E., Maurice, M., Housset, C., Callebaut, I., Aït-Slimane, T., 2017. Functional defect of variants in the ATP-binding sites of ABCB4 and their rescue by the CFTR potentiator, Ivacaftor (VX-770). Hepatology 65 (2), 560-570.

Denk, G.U., Bikker, H., Lekanne Dit Deprez, R.H., Terpstra, V., van der Loos, C., Beuers, U., Rust, C., Pusl, T., 2010. ABCB4 deficiency: A family saga of early onset cholelithiasis, sclerosing cholangitis and cirrhosis and a novel mutation in the ABCB4 gene. Hepatol. Res. 40 (9), 937-941.

Dixon, P.H., Weerasekera, N., Linton, K.J., Donaldson, O., Chambers, J., Egginton, E;, Weaver, J; Nelson-Piercy, C., de Swie,t M;, Warnes, G., Elias, E., Higgins, C.F., Johnston, D.G., McCarthy, M.I., Williamson, C., 2000. Heterozygous MDR3 missense 
mutation associated with intrahepatic cholestasis of pregnancy: evidence for a defect in protein trafficking. Hum. Mol. Genet. 9 (8), 1209-1217.

Dzagania, T., Engelmann, G., Häussinger, D., Schmitt, L., Flechtenmacher, C., Rtskhiladze, I., Kubitz, R., 2012. The histidine-loop is essential for transport activity of human MDR3. A novel mutation of MDR3 in a patient with progressive familial intrahepatic cholestasis type 3. Gene 506 (1), 141-145.

Fang, L.J., Wang, X.H., Knisely, A.S., Yu, H., Lu, Y., Liu, L.Y., Wang, J.S., 2012. Chinese children with chronic intrahepatic cholestasis and high $\gamma$-glutamyl transpeptidase: clinical features and association with ABCB4 mutations. J. Pediatr. Gastroenterol. Nutr. 55 (2), $150-156$.

Floreani, A., Carderi, I., Paternoster, D., Soardo, G., Azzaroli, F., Esposito, W., Variola, A., Tommasi, A.M., Marchesoni, D., Braghin, C., Mazzella, G., 2006. Intrahepatic cholestasis of pregnancy: three novel MDR3 gene mutations. Aliment. Pharmacol. Ther. 23 (11), $1649-1653$.

Floreani, A., Carderi, I., Paternoster, D., Soardo, G., Azzaroli, F., Esposito, W., Montagnani, M., Marchesoni, D., Variola, A., Rosa Rizzotto, E., Braghin, C., Mazzella, G., 2008. Hepatobiliary phospholipid transporter ABCB4, MDR3 gene variants in a large cohort of Italian women with intrahepatic cholestasis of pregnancy. Dig. Liver Dis. 40 (5), 366-370.

Frousios, K., Iliopoulos, C.S., Schlitt, T., Simpson, M.A., 2013. Predicting the functional consequences of non-synonymous DNA sequence variants - evaluation of bioinformatics tools and development of a consensus strategy. Genomics 102 (4), 223-228.

Gautherot, J., Durand-Schneider, A.M., Delautier, D., Delaunay, J.L;, Rada, A., Gabillet, J., Housset, C., Maurice, M., Aït-Slimane, T., 2012. Effects of cellular, chemical, and pharmacological chaperones on the rescue of a trafficking-defective mutant of the ATPbinding cassette transporter proteins ABCB1/ABCB4. J. Biol. Chem. 287 (7), 5070-5078.

Gautherot, J., Delautier, D., Maubert, M.A., Aït-Slimane, T., Bolbach, G., Delaunay, J.L., Durand-Schneider, A.M., Firrincieli, D., Barbu, V., Chignard, N., Housset, C., Maurice, M., Falguières, T., 2014. Phosphorylation of ABCB4 impacts its function: insights from disease-causing mutations. Hepatology 60 (2), 610-621.

Geenes, V., Williamson C., 2009. Intrahepatic cholestasis of pregnancy. World. J. Gastroenterol. 15 (17), 2049-2066.

Gonzales, E;, Davit-Spraul, A., Baussan, C., Buffet, C., Maurice, M., Jacquemin, E., 2009. Liver diseases related to MDR3 (ABCB4) gene deficiency. Front. Biosci. (Landmark Ed.) $14,4242-4256$.

Gordo-Gilart, R., Andueza, S., Hierro, L., Martínez-Fernández, P., D'Agostino, D., Jar,a P., Alvarez, L., 2015. Functional analysis of ABCB4 mutations relates clinical outcomes of progressive familial intrahepatic cholestasis type 3 to the degree of MDR3 floppase activity. Gut 64 (1), 147-155.

Gordo-Gilart, R., Hierro, L., Andueza, S., Muñoz-Bartolo, G., López, C., Díaz, C., Jar,a P., Álvarez, L., 2016. Heterozygous ABCB4 mutations in children with cholestatic liver disease. Liver Int. 36 (2), 258-267.

Gotthardt, D., Runz, H., Keitel, V., Fischer, C., Flechtenmacher, C., Wirtenberger, M., Weiss, K.H., Imparato, S., Braun, A., Hemminki, K., Stremmel, W., Rüschendorf, F., Stiehl, A., Kubitz, R., Burwinkel, B., Schirmacher, P., Knisely, A.S., Zschocke, J., Sauer, P, 2008. A mutation in the canalicular phospholipid transporter gene, ABCB4, is associated with cholestasis, ductopenia, and cirrhosis in adults. Hepatology 48 (4), 1157-1166.

Guex, N., Peitsch, M.C., 1997. SWISS-MODEL and the Swiss-PdbViewer: an environment for comparative protein modeling. Electrophoresis 18 (15), 2714-2723. 
Hopf, C., Beuers, U., Bikker, H., Denk, G.U., Rust, C., 2011. [44-year-old woman with elevated liver enzymes and a family history for cholelithiasis]. Internist (Berl). 52 (10), 1234-1237.

Jacquemin, E., De Vree, J.M., Cresteil, D., Sokal, E.M., Sturm, E., Dumont, M., Scheffer, G.L., Paul, M., Burdelski, M., Bosma, P.J., Bernard, O., Hadchoue,l M., Elferink, R.P., 2001. The wide spectrum of multidrug resistance 3 deficiency: from neonatal cholestasis to cirrhosis of adulthood. Gastroenterology 120 (6), 1448-1458.

Källberg, M., Margaryan, G., Wang, S., Ma, J., Xu, J., 2014. RaptorX server: a resource for template-based protein structure modeling. Methods Mol. Biol. 1137, 17-27.

Kast, C., Canfield, V., Levenson, R., Gros, P., 1995. Membrane topology of P-glycoprotein as determined by epitope insertion: transmembrane organization of the $\mathrm{N}$-terminal domain of mdr3. Biochemistry 34 (13), 4402-4411.

Keitel, V., Burdelski, M., Warskulat, U., Kühlkamp, T., Keppler, D., Häussinger, D., Kubitz, R., 2005. Expression and localization of hepatobiliary transport proteins in progressive familial intrahepatic cholestasis. Hepatology 41 (5), 1160-1172.

Kubitz, R., Bode, J., Erhardt, A., Graf, D., Kircheis, G., Müller-Stöver, I., Reinehr, R., Reuter, S., Richter, J., Sagir, A., Schmitt, M., Donner, M. , 2011 Cholestatic liver diseases from child to adult: the diversity of MDR3 disease. Z. Gastroenterol. 49 (6): 728-736.

Kumar, A., Rajendran, V., Sethumadhavan, R., Shukla, P., Tiwari, S., Purohit, R., 2014. Computational SNP analysis: Current approaches and future prospects. Cell. Biophys. 68 (2), 233-239.

Lang, C., Meier, Y., Stieger, B., Beuers, U., Lang, T., Kerb, R., Kullak-Ublick, G.A., Meier, P.J., Pauli-Magnus. C, 2007. Mutations and polymorphisms in the bile salt export pump and the multidrug resistance protein 3 associated with drug-induced liver injury. Pharmacogenet. Genomics 17 (1), 47-60.

Li, B., Krishnan, V.G., Mort, M.E., Xin, F., Kamati, K.K., Cooper, D.N., Mooney, S.D., Radivojac, P., 2009. Automated inference of molecular mechanisms of disease from amino acid substitutions. Bioinformatics 25 (21), 2744-2750.

Müllenbach, R., Linton, K.J., Wiltshire, S., Weerasekera, N., Chambers, J., Elias, E., Higgins, C.F., Johnston, D.G., McCarthy, M.I., Williamson, C., 2003. ABCB4 gene sequence variation in women with intrahepatic cholestasis of pregnancy. J. Med. Genet. 40 (5), e70.

Ng, P.C., Henikoff, S., 2006. Predicting the effects of amino acid substitutions on protein function. Annu. Rev. Genomics Hum. Genet. 7, 61-80.

Omasits, U., Ahrens, C.H., Müller, S., Wollscheid, B., 2014. Protter: interactive protein feature visualization and integration with experimental proteomic data. Bioinformatics 30 (6), 884-886.

Pauli-Magnus, C., Lang, T., Meier, Y., Zodan-Marin, T., Jung, D., Breymann, C., Zimmermann, R., Kenngott, S., Beuers, U., Reichel, C., Kerb, R., Penger, A., Meier, P.J., Kullak-Ublick, G.A., 2004. Sequence analysis of bile salt export pump (ABCB11) and multidrug resistance p-glycoprotein 3 (ABCB4, MDR3) in patients with intrahepatic cholestasis of pregnancy. Pharmacogenetics 14 (2), 91-102.

Poupon, R., Barbu, V., Chamouard, P., Wendum, D., Rosmorduc, O., Housset, C., 2010a. Combined features of low phospholipid-associated cholelithiasis and progressive familial intrahepatic cholestasis 3. Liver Int. 30 (2), 327-331.

Poupon, R., Arrive, L., Rosmorduc, O., 2010b. The cholangiographic features of severe forms of ABCB4/MDR3 deficiency-associated cholangiopathy in adults. Gastroenterol. Clin. Biol. 34 (6-7), 380-387.

Poupon, R., Rosmorduc, O., Boëlle, P.Y., Chrétien, Y., Corpechot, C., Chazouillères, O., Housset, C., Barbu, V., 2013. Genotype-phenotype relationships in the low-phospholipid- 
associated cholelithiasis syndrome: a study of 156 consecutive patients. Hepatology 58 (3), 1105-1110.

Rosmorduc, O., Hermelin, B., Poupon, R., 2001. MDR3 gene defect in adults with symptomatic intrahepatic and gallbladder cholesterol cholelithiasis. Gastroenterology 120 (6), 1459-1467.

Rosmorduc, O., Hermelin, B., Boelle, P.Y., Parc, R., Taboury, J., Poupon, R., 2003. ABCB4 gene mutation-associated cholelithiasis in adults. Gastroenterology 125 (2), 452-459.

Smit, J.J., Schinkel, A.H., Oude Elferink, R.P., Groen, A.K., Wagenaar, E., van Deemter, L., Mol, C.A., Ottenhoff, R., van der Lugt, N.M., van Roon, M.A., van der Valk, M.A., Offerhaus, G.J.A., Berns, A.J.M., Borst, P., 1993. Homozygous disruption of the murine mdr2 P-glycoprotein gene leads to a complete absence of phospholipid from bile and to liver disease. Cell 75 (3), 451-462.

Thusberg, J., Vihinen, M., 2009. Pathogenic or not? And if so, then how? Studying the effects of missense mutations using bioinformatics methods. Hum. Mutat. 30 (5), 703-714.

Thusberg, J., Olatubosun, A., Vihinen, M., 2011. Performance of mutation pathogenicity prediction methods on missense variants. Hum. Mutat. 32 (4), 358-368.

Van Nieuwkerk CM, Elferink RP, Groen AK, Ottenhoff R, Tytgat GN, Dingemans KP, Van Den Bergh Weerman MA, Offerhaus GJ., 1996. Effects of ursodeoxycholate and cholate feeding on liver disease in FVB mice with a disrupted mdr2 P-glycoprotein gene. Gastroenterology 111(1),165-171.

Ziol, M., Barbu, V., Rosmorduc, O., Frassati-Biaggi, A., Barget, N., Hermelin, B., Scheffer, G.L., Bennouna, S., Trinchet, J.C., Beaugrand, M., Ganne-Carrié, N., 2008. ABCB4 heterozygous gene mutations associated with fibrosing cholestatic liver disease in adults. Gastroenterology 135 (1), 131-141.

Zolnerciks, J.K., Andress, E.J., Nicolaou, M., Linton, K.J., 2011. Structure of ABC transporters. Essays Biochem. 50 (1), 43-61. 


\section{Legend to figures}

Fig. 1. In silico analysis of the ABCB4 sequences encompassing the E528D and P1161S variations. (A) Alignment of ABCB4 sequences from different species using the Clustal Omega program. The sequences include E528 or P1161 and the signature sequences. (B and

C) Three-dimensional structure of the peptide 526-539 with E (Glu) or D (Asp) at position 528 (B), and of the peptide 1159-1181 with P (Pro) or S (Ser) at position 1161 (C). The models were built by homology with the structure of $C$. elegans, and visualized using SwissPDB viewer. The wt residue is colored in yellow, the mutated one in green, and the signature in purple. Hydrogen bonds are indicated by green dotted lines. The mutation E528D adds a novel hydrogen bond between S534 and Q535 in the signature (indicated by a red arrow in B, right panel). The mutation P1161S introduces a hydrogen bond between P1161 and H1162 (red arrow in C, right panel), and removes the hydrogen bond between D1170 and K1171 (red arrow in $\mathrm{C}$, left panel).

Fig. 2. Expression of ABCB4 mutants in transfected cells. HepG2 cells (A) or HEK293 cells (B) transiently expressing wt ABCB4 or the indicated mutants were fixed, permeabilized and stained with the P3II-26 monoclonal antibody against ABCB4, followed by Alexa-Fluor 488conjugated secondary antibody. Nuclei were stained with Draq5 (blue). Images were obtained by confocal microscopy. Bile canaliculi are indicated by arrows. Bars, $10 \mu \mathrm{m}$. (C) Control HEK293 cells (Ctrl) or HEK293 cells transiently expressing wt ABCB4 or the mutants were lyzed and analyzed by electrophoresis and immunoblotting using the P3II-26 anti-ABCB4 antiboby. The same amount of protein was loaded in each lane. Standard molecular mass is indicated in $\mathrm{kDa}$.

Fig. 3. Phosphatidylcholine secretion by ABCB4 mutants. Phosphatidylcholine (PC) secretion was measured in HEK293 cells transfected with plasmids encoding wt ABCB4 or the 
indicated mutants. Cells were incubated in serum-free media containing sodium taurocholate and BSA for 24 hours, and the amount of secreted phosphatidylcholine was measured. Results are expressed as the percentage of phosphatidylcholine secretion relative to wt $\mathrm{ABCB} 4$ expressing cells, after normalization to ABCB4 mature protein levels. Results are means ( \pm SEM) of five independent experiments. $* P<0.01, * * P<0.001$. 
Table 1. Characteristics of patients with the E528D and P1161S ABCB4 variations

\begin{tabular}{|c|c|c|c|c|c|}
\hline $\begin{array}{c}\text { Patient } \\
\text { n }^{\circ} / \text { gender }\end{array}$ & $\begin{array}{l}\text { Nucleotide } \\
\text { change }\end{array}$ & $\begin{array}{l}\text { Amino acid } \\
\text { change }\end{array}$ & Status & Diagnosis & Reference \\
\hline $1 / \mathrm{F}$ & $\begin{array}{l}\text { c. } 1584 G>C \\
\text { c. } 1954 A>G\end{array}$ & $\begin{array}{l}\text { p.E528D } \\
\text { p.R652G }\end{array}$ & $\begin{array}{l}\text { HTZ } \\
\text { HTZ }\end{array}$ & LPAC & Rosmorduc et al., 2003 \\
\hline $2 / \mathrm{F}$ & c. $1584 \mathrm{G}>\mathrm{C}$ & p.E528D & HTZ & $\mathrm{ICP}$ & Rosmorduc et al., 2003 \\
\hline $3 * / \mathrm{F}$ & c. $1584 \mathrm{G}>\mathrm{C}$ & p.E528D & HTZ & LPAC & Poupon et al., 2013 \\
\hline $4 / \mathrm{F}$ & c. $1584 \mathrm{G}>\mathrm{C}$ & p.E528D & HTZ & LPAC & Poupon et al., 2013 \\
\hline $5 / \mathrm{F}$ & c. $1584 \mathrm{G}>\mathrm{C}$ & p.E528D & HTZ & LPAC & this study \\
\hline $6 / \mathrm{F}$ & $\begin{array}{l}\text { c. } 1584 G>C \\
\text { c. } 1954 A>G\end{array}$ & $\begin{array}{l}\text { p.E528D } \\
\text { p.R652G }\end{array}$ & $\begin{array}{l}\text { HTZ } \\
\text { HMZ }\end{array}$ & LPAC & this study \\
\hline $7 / \mathrm{F}$ & $\begin{array}{l}\text { c. } 1584 G>C \\
\text { c. } 1954 A>G\end{array}$ & $\begin{array}{l}\text { p.E528D } \\
\text { p.R652G }\end{array}$ & $\begin{array}{l}\text { HTZ } \\
\text { HMZ }\end{array}$ & LPAC & this study \\
\hline $8 / \mathrm{M}$ & c. $3481 \mathrm{C}>\mathrm{T}$ & p.P1161S & HTZ & LPAC & Rosmorduc et al., 2001 \\
\hline $9 * * / \mathrm{F}$ & c. $3481 \mathrm{C}>\mathrm{T}$ & p.P1161S & HTZ & LPAC & Poupon et al., 2013 \\
\hline
\end{tabular}

Numbering of the nucleotides corresponds to NM_000443.3 (ABCB4, transcript variant A, mRNA). Abbreviations: LPAC, low phospholipid-associated cholelithiasis; ICP, intrahepatic cholestasis of pregnancy; HTZ, heterozygous; HMZ, homozygous.

* Daughter of patient 2.

***Daughter of patient 8 . 
Table 2. Prediction scores for the E528D and P1161S ABCB4 variants

\begin{tabular}{lcc}
\hline & E528D & P1161S \\
\hline Provean & -1.32 & \\
& benign & -6.78 \\
& deleterious \\
\hline Polyphen-2 & 0.001 & 0.932 \\
\hline benign & deleterious \\
\hline MutPred & disease-related & disease-related \\
\hline & 0.52 & 0.88 \\
\hline
\end{tabular}

Provean: a score equal or below -2.5 qualifies the substitution as deleterious.

Polyphen-2: values range from 0 to 1 . The substitution is predicted to be damaging if $>0.5$ and benign if $<0.5$.

PhD-SNP: a binary classification is provided : disease-related or polymorphism.

MutPred: a probability of deleterious effect is attributed to each substitution. 
Table 3. In silico predictions of ABCB4 missense variants with a known biological effect

\begin{tabular}{|c|c|c|c|c|c|c|}
\hline & MutPred $^{\mathrm{a}}$ & $\begin{array}{l}\text { PhD- } \\
\text { SNP }\end{array}$ & $\begin{array}{c}\text { Poly-phen } \\
2\end{array}$ & Provean & $\begin{array}{c}\text { In cellulo } \\
\text { effect }\end{array}$ & Reference \\
\hline G535D & $96.0 \%$ & Disease & $\begin{array}{c}\text { Probably } \\
\text { damaging }\end{array}$ & Deleterious & $\begin{array}{l}\text { Activity } \\
\text { defect }\end{array}$ & $\begin{array}{c}\text { Delaunay et al., } \\
2017\end{array}$ \\
\hline G536R & $93.9 \%$ & Disease & $\begin{array}{c}\text { Probably } \\
\text { damaging }\end{array}$ & Deleterious & $\begin{array}{l}\text { Activity } \\
\text { defect }\end{array}$ & $\begin{array}{c}\text { Delaunay et al., } \\
2017\end{array}$ \\
\hline I541F & $92.8 \%$ & Disease & $\begin{array}{c}\text { Probably } \\
\text { damaging }\end{array}$ & Deleterious & $\begin{array}{c}\text { Maturation } \\
\text { defect }\end{array}$ & $\begin{array}{c}\text { Delaunay et al., } \\
2009\end{array}$ \\
\hline L556R & $96.1 \%$ & Disease & $\begin{array}{l}\text { Probably } \\
\text { damaging }\end{array}$ & Deleterious & $\begin{array}{c}\text { Maturation } \\
\text { defect }\end{array}$ & $\begin{array}{c}\text { Delaunay et al., } \\
2016\end{array}$ \\
\hline S1076C & $95.5 \%$ & Disease & $\begin{array}{l}\text { Probably } \\
\text { damaging }\end{array}$ & Deleterious & $\begin{array}{l}\text { Activity } \\
\text { defect }\end{array}$ & $\begin{array}{c}\text { Delaunay et al., } \\
2017\end{array}$ \\
\hline S1176L & $94.2 \%$ & Disease & $\begin{array}{l}\text { Probably } \\
\text { damaging }\end{array}$ & Deleterious & $\begin{array}{l}\text { Activity } \\
\text { defect }\end{array}$ & $\begin{array}{c}\text { Delaunay et al., } \\
2017\end{array}$ \\
\hline G1178S & $98.1 \%$ & Disease & $\begin{array}{c}\text { Probably } \\
\text { damaging }\end{array}$ & Deleterious & $\begin{array}{c}\text { Activity } \\
\text { defect }\end{array}$ & $\begin{array}{c}\text { Delaunay et al., } \\
2017\end{array}$ \\
\hline R47G & $59.3 \%$ & Disease & $\begin{array}{l}\text { Probably } \\
\text { damaging }\end{array}$ & Deleterious & $\begin{array}{l}\text { Activity } \\
\text { defect }\end{array}$ & $\begin{array}{l}\text { Gautherot et } \\
\text { al., } 2014\end{array}$ \\
\hline S346I & $71.2 \%$ & Disease & Benign & Deleterious & $\begin{array}{l}\text { Activity } \\
\text { defect }\end{array}$ & $\begin{array}{c}\text { Delaunay et al., } \\
2016\end{array}$ \\
\hline F357L & $88.1 \%$ & Neutral & Benign & Deleterious & $\begin{array}{l}\text { Activity } \\
\text { defect }\end{array}$ & $\begin{array}{c}\text { Delaunay et al., } \\
2016\end{array}$ \\
\hline T424A & $85.1 \%$ & Neutral & $\begin{array}{c}\text { Probably } \\
\text { damaging }\end{array}$ & Deleterious & $\begin{array}{l}\text { Stability } \\
\text { defect }\end{array}$ & $\begin{array}{c}\text { Delaunay et al., } \\
2016\end{array}$ \\
\hline N510S & $68.8 \%$ & Disease & $\begin{array}{l}\text { Probably } \\
\text { damaging }\end{array}$ & Deleterious & $\begin{array}{l}\text { Stability } \\
\text { defect }\end{array}$ & $\begin{array}{c}\text { Delaunay et al., } \\
2016\end{array}$ \\
\hline E528D & $52.2 \%$ & Disease & Benign & Neutral & $\begin{array}{l}\text { Activity } \\
\text { defect }\end{array}$ & This study \\
\hline P726L & $83.8 \%$ & Disease & $\begin{array}{l}\text { Probably } \\
\text { damaging }\end{array}$ & Deleterious & $\begin{array}{l}\text { Activity } \\
\text { defect }\end{array}$ & $\begin{array}{c}\text { Delaunay et al., } \\
2016\end{array}$ \\
\hline T775M & $74.1 \%$ & Disease & $\begin{array}{l}\text { Probably } \\
\text { damaging }\end{array}$ & Neutral & $\begin{array}{l}\text { Activity } \\
\text { defect }\end{array}$ & $\begin{array}{c}\text { Delaunay et al., } \\
2016\end{array}$ \\
\hline Q855L & $72.2 \%$ & Neutral & $\begin{array}{l}\text { Probably } \\
\text { damaging }\end{array}$ & Deleterious & $\begin{array}{c}\text { Maturation } \\
\text { defect }\end{array}$ & $\begin{array}{c}\text { Delaunay et al., } \\
2016\end{array}$ \\
\hline G954S & $82.2 \%$ & Neutral & $\begin{array}{l}\text { Probably } \\
\text { damaging }\end{array}$ & Neutral & $\begin{array}{l}\text { Activity } \\
\text { defect }\end{array}$ & $\begin{array}{c}\text { Delaunay et al., } \\
2016\end{array}$ \\
\hline P1161S & $88.2 \%$ & Disease & $\begin{array}{l}\text { Probably } \\
\text { damaging }\end{array}$ & Deleterious & $\begin{array}{c}\text { Activity } \\
\text { defect }\end{array}$ & This study \\
\hline
\end{tabular}




\begin{tabular}{|c|c|c|c|c|c|c|}
\hline T34M & $30 \%$ & Neutral & Benign & Neutral & $\begin{array}{c}\text { Activity } \\
\text { defect }\end{array}$ & $\begin{array}{c}\text { Gautherot et } \\
\text { al., } 2014\end{array}$ \\
\hline T175A & $40.5 \%$ & Neutral & $\begin{array}{l}\text { Probably } \\
\text { damaging }\end{array}$ & Deleterious & $\begin{array}{c}\text { No detectable } \\
\text { defect }\end{array}$ & $\begin{array}{c}\text { Delaunay et al., } \\
2016\end{array}$ \\
\hline R652G & $23.5 \%$ & Disease & Benign & Neutral & $\begin{array}{c}\text { No detectable } \\
\text { defect }\end{array}$ & $\begin{array}{c}\text { Delaunay et al., } \\
2016\end{array}$ \\
\hline
\end{tabular}

${ }^{\mathrm{a}} \mathrm{A}$ value $>50 \%$ is considered as deleterious.

Predictions noted in bold characters are in contradiction with the biological effect. 
Table 4. Accuracy of the prediction programs in accordance with in cellulo effect of ABCB4 mutations

\begin{tabular}{lcccc}
\hline Prediction $^{\text {a }}$ & MutPred & PhD-SNP & Poly-Phen2 & Provean \\
\hline True pathogenic & 18 & 14 & 15 & 15 \\
True benign & 2 & 1 & 1 & 1 \\
False pathogenic & 0 & 1 & 1 & 1 \\
False benign & 1 & 5 & 4 & 4 \\
\hline Correct prediction & $20 / 21$ & $15 / 21$ & $17 / 21$ & $17 / 21$ \\
& $(95 \%)$ & $(71 \%)$ & $(80 \%)$ & $(80 \%)$ \\
\hline
\end{tabular}

${ }^{a}$ Predictions in accordance with the in cellulo phenotype are classified as "true" and predictions in contradiction are classified as "false" 
Table 5. In silico predictions of disease-associated ABCB4 missense variants reported in the Human Gene Mutation Database

\begin{tabular}{|c|c|c|c|c|c|c|}
\hline mutation & $\begin{array}{c}\text { Clinical } \\
\text { phenotype }\end{array}$ & MutPred $^{\mathrm{a}}$ & $\begin{array}{l}\text { PhD- } \\
\text { SNP }\end{array}$ & $\begin{array}{l}\text { Poly- } \\
\text { phen2 }\end{array}$ & Provean & Reference \\
\hline R47Q & LPAC & $60.7 \%$ & Neutral & $\begin{array}{c}\text { Probably } \\
\text { Damaging }\end{array}$ & Deleterious & $\begin{array}{c}\text { Davit-Spraul et al. } \\
2010\end{array}$ \\
\hline L73V & PFIC3 & $53.4 \%$ & Disease & $\begin{array}{l}\text { Probably } \\
\text { damaging }\end{array}$ & Neutral & Colombo et al., 2011 \\
\hline G126E & PFIC3 & $94.7 \%$ & Disease & $\begin{array}{l}\text { Probably } \\
\text { Damaging }\end{array}$ & Deleterious & Degiorgio et al., 2007 \\
\hline W138R & PFIC3 & $92.2 \%$ & Neutral & $\begin{array}{l}\text { Probably } \\
\text { Damaging }\end{array}$ & Deleterious & Jacquemin et al., 2001 \\
\hline R150K & ICP & $96.9 \%$ & Disease & $\begin{array}{l}\text { Probably } \\
\text { Damaging }\end{array}$ & Neutral & $\begin{array}{c}\text { Müllenbach et al., } \\
2003\end{array}$ \\
\hline F165I & LPAC & $94.6 \%$ & Disease & $\begin{array}{l}\text { Probably } \\
\text { damaging }\end{array}$ & Deleterious & $\begin{array}{l}\text { Rosmorduc et al., } \\
2003\end{array}$ \\
\hline N168D & ICP & $63.3 \%$ & Disease & Benign & Neutral & Bacq et al., 2009 \\
\hline R176W & PFIC3 & $86.2 \%$ & Disease & $\begin{array}{l}\text { Probably } \\
\text { damaging }\end{array}$ & Deleterious & $\begin{array}{c}\text { Davit-Spraul et al. } \\
2010\end{array}$ \\
\hline A250P & PFIC3 & $93.3 \%$ & Disease & $\begin{array}{l}\text { Probably } \\
\text { Damaging }\end{array}$ & Deleterious & Degiorgio et al., 2007 \\
\hline A286V & PFIC3 & $87.4 \%$ & Disease & $\begin{array}{l}\text { Probably } \\
\text { damaging }\end{array}$ & deleterious & Degiorgio et al., 2007 \\
\hline M301T & LPAC & $68.7 \%$ & Neutral & Benign & Deleterious & $\begin{array}{c}\text { Rosmorduc et al., } \\
2003\end{array}$ \\
\hline G319E & LPAC & $64.8 \%$ & Disease & $\begin{array}{c}\text { Probably } \\
\text { Damaging }\end{array}$ & Deleterious & Hopf et al., 2011 \\
\hline S320F & LPAC & $73.8 \%$ & Disease & $\begin{array}{l}\text { Probably } \\
\text { damaging }\end{array}$ & rious & $\begin{array}{c}\text { Rosmorduc et al., } \\
2001\end{array}$ \\
\hline A358P & PFIC3 & $62.1 \%$ & Disease & Benign & Deleterious & $\begin{array}{c}\text { Davit-Spraul et al. } \\
2010\end{array}$ \\
\hline A364V & PFIC3 & $89.7 \%$ & Disease & $\begin{array}{l}\text { Probably } \\
\text { damaging }\end{array}$ & Deleterious & Degiorgio et al., 2007 \\
\hline G384R & LPAC & $45.8 \%$ & Disease & $\begin{array}{c}\text { Probably } \\
\text { Damaging } \\
\end{array}$ & Deleterious & Poupon et al., 2010b \\
\hline E395G & PFIC3 & $81.9 \%$ & Disease & $\begin{array}{c}\text { Probably } \\
\text { Damaging }\end{array}$ & Deleterious & Jacquemin et al., 2001 \\
\hline $\mathrm{Y} 403 \mathrm{H}$ & PFIC3 & $97.8 \%$ & Disease & $\begin{array}{l}\text { Probably } \\
\text { Damaging }\end{array}$ & Deleterious & Degiorgio et al., 2007 \\
\hline R406Q & LPAC & $78 \%$ & Disease & $\begin{array}{l}\text { Probably } \\
\text { Damaging }\end{array}$ & Deleterious & Poupon et al., 2010b \\
\hline $\mathrm{V} 425 \mathrm{M}$ & PFIC3 & $84.4 \%$ & Neutral & $\begin{array}{l}\text { Probably } \\
\text { Damaging }\end{array}$ & Neutral & Jacquemin et al., 2001 \\
\hline L445V & LPAC & $82.3 \%$ & Disease & $\begin{array}{l}\text { Probably } \\
\text { Damaging }\end{array}$ & Neutral & $\begin{array}{c}\text { Davit-Spraul et al. } \\
2010\end{array}$ \\
\hline D459G & PFIC3 & $76.9 \%$ & Disease & $\begin{array}{l}\text { Probably } \\
\text { Damaging }\end{array}$ & Deleterious & Fang et al., 2012 \\
\hline V475A & PFIC3 & $95.6 \%$ & Disease & $\begin{array}{c}\text { Probably } \\
\text { Damaging }\end{array}$ & Deleterious & Degiorgio et al., 2007 \\
\hline $\mathrm{P} 479 \mathrm{~L}$ & PFIC3 & $88.4 \%$ & Disease & Probably & Deleterious & Davit-Spraul et al. \\
\hline
\end{tabular}




\begin{tabular}{|c|c|c|c|c|c|c|}
\hline & & & & Damaging & & 2010 \\
\hline L481R & PFIC3 & $88.4 \%$ & Disease & $\begin{array}{l}\text { Probably } \\
\text { damaging }\end{array}$ & Deleterious & Degiorgio et al., 2014 \\
\hline A511T & PFIC3 & $91.1 \%$ & Disease & $\begin{array}{c}\text { Probably } \\
\text { Damaging }\end{array}$ & Deleterious & Degiorgio et al., 2007 \\
\hline E513K & LPAC & $63 \%$ & Disease & Benign & Deleterious & $\begin{array}{l}\text { Davit-Spraul et al. } \\
2010\end{array}$ \\
\hline V526F & $\begin{array}{l}\text { Anicteric } \\
\text { cholestasis }\end{array}$ & $96.3 \%$ & Disease & $\begin{array}{l}\text { Probably } \\
\text { Damaging }\end{array}$ & Deleterious & Ziol et al, 2008 \\
\hline R545G & $\begin{array}{l}\text { Anicteric } \\
\text { cholestasis }\end{array}$ & $99.2 \%$ & Disease & $\begin{array}{c}\text { Probably } \\
\text { Damaging }\end{array}$ & Deleterious & Ziol et al, 2008 \\
\hline A546D & ICP & $93.5 \%$ & Disease & $\begin{array}{l}\text { Probably } \\
\text { Damaging }\end{array}$ & Deleterious & Dixon et al., 2000 \\
\hline R549H & ICP & $80.5 \%$ & Disease & $\begin{array}{c}\text { Probably } \\
\text { Damaging }\end{array}$ & Deleterious & Floreani et al., 2006 \\
\hline E558K & PFIC3 & $97.6 \%$ & Disease & $\begin{array}{c}\text { Probably } \\
\text { Damaging }\end{array}$ & Deleterious & Degiorgio et al., 2007 \\
\hline D564G & PFIC3 & $95.7 \%$ & Disease & Benign & Deleterious & Jacquemin et al., 2001 \\
\hline R582Q & PFIC3 & $74.1 \%$ & Disease & $\begin{array}{l}\text { Probably } \\
\text { Damaging }\end{array}$ & Deleterious & Fang et al., 2012 \\
\hline R590Q & PFIC3 & $76.2 \%$ & Disease & $\begin{array}{c}\text { Probably } \\
\text { Damaging }\end{array}$ & Deleterious & Degiorgio et al., 2007 \\
\hline L591Q & LPAC & $96 \%$ & Disease & $\begin{array}{l}\text { Probably } \\
\text { Damaging }\end{array}$ & Deleterious & $\begin{array}{c}\text { Rosmorduc et al., } \\
2003\end{array}$ \\
\hline T593A & PFIC3 & $85 \%$ & Neutral & $\begin{array}{l}\text { Probably } \\
\text { Damaging }\end{array}$ & Deleterious & Degiorgio et al., 2007 \\
\hline M630V & PFIC3 & $78 \%$ & Neutral & Benign & Neutral & Degiorgio et al., 2007 \\
\hline T667I & ICP & $34 \%$ & Neutral & Benign & Neutral & Floreani et al., 2008 \\
\hline L701P & PFIC3 & $94.9 \%$ & Disease & $\begin{array}{c}\text { Probably } \\
\text { Damaging }\end{array}$ & Deleterious & Degiorgio et al., 2007 \\
\hline F711S & PFIC3 & $81 \%$ & Neutral & $\begin{array}{l}\text { Probably } \\
\text { Damaging }\end{array}$ & Deleterious & Jacquemin et al., 2001 \\
\hline T715I & PFIC3 & $81.9 \%$ & Neutral & Benign & Neutral & Degiorgio et al., 2007 \\
\hline G723E & PFIC3 & $86.4 \%$ & Disease & $\begin{array}{l}\text { Probably } \\
\text { Damaging }\end{array}$ & Deleterious & Degiorgio et al., 2007 \\
\hline P726T & PFIC3 & $91.5 \%$ & Disease & $\begin{array}{l}\text { Probably } \\
\text { Damaging }\end{array}$ & Deleterious & Degiorgio et al., 2007 \\
\hline $\mathrm{A} 737 \mathrm{~V}$ & PFIC3 & $83.6 \%$ & Disease & Benign & Neutral & Degiorgio et al., 2007 \\
\hline $\mathrm{I} 738 \mathrm{~L}$ & $\begin{array}{c}\text { Anicteric } \\
\text { cholestasis }\end{array}$ & $78.2 \%$ & Neutral & Benign & Neutral & Ziol et al, 2008 \\
\hline G762E & $\begin{array}{c}\text { ICP, } \\
\text { PFIC3 }\end{array}$ & $93.6 \%$ & Disease & $\begin{array}{c}\text { Probably } \\
\text { Damaging }\end{array}$ & Deleterious & $\begin{array}{l}\text { Pauli-Magnus et al., } \\
2004 \\
\text { Degiorgio et al., } 2007\end{array}$ \\
\hline $\mathrm{I764L}$ & $\begin{array}{c}\text { Drug-induced } \\
\text { cholestasis }\end{array}$ & $83.8 \%$ & Disease & Benign & Neutral & Lang et al., 2007 \\
\hline G773R & LPAC & $85.6 \%$ & Disease & $\begin{array}{c}\text { Probably } \\
\text { Damaging }\end{array}$ & Deleterious & $\begin{array}{c}\text { Davit-Spraul et al. } \\
2010 \\
\end{array}$ \\
\hline $\mathrm{R} 788 \mathrm{E}$ & LPAC & $84.2 \%$ & Disease & $\begin{array}{l}\text { Probably } \\
\text { Damaging }\end{array}$ & Deleterious & $\begin{array}{c}\text { Rosmorduc et al., } \\
2003\end{array}$ \\
\hline R788W & $\begin{array}{l}\text { Cholestasis, } \\
\text { ICP }\end{array}$ & $95.7 \%$ & Disease & $\begin{array}{l}\text { Probably } \\
\text { Damaging }\end{array}$ & Deleterious & Gotthardt et al, 2008 \\
\hline A840D & PFIC3 & $94.2 \%$ & Disease & $\begin{array}{l}\text { Probably } \\
\text { Damaging }\end{array}$ & Deleterious & Degiorgio et al., 2007 \\
\hline L859W & LPAC & $64.6 \%$ & Disease & Probably & Deleterious & Davit-Spraul et al. \\
\hline
\end{tabular}




\begin{tabular}{|c|c|c|c|c|c|c|}
\hline A934T & LPAC & $87.7 \%$ & Neutral & $\begin{array}{c}\text { Damaging } \\
\text { Probably } \\
\text { Damaging }\end{array}$ & Deleterious & Rosmorduc et al., \\
2003
\end{tabular}

${ }^{\mathrm{a}} \mathrm{A}$ value $>50 \%$ is considered as deleterious.

Prediction of benign mutations is noted in bold characters. 
Table 6. Scoring of in silico prediction programs for disease-associated ABCB4 mutations of the Human Gene Mutation Database.

\begin{tabular}{lcccc}
\hline Prediction & MutPred & PhD-SNP & Poly-Phen2 & Provean \\
\hline Pathogenic & 63 & 52 & 54 & 54 \\
Benign & 2 & 13 & 11 & 11 \\
\hline Score & $97 \%$ & $80 \%$ & $83 \%$ & $83 \%$ \\
\hline
\end{tabular}


$\downarrow \quad \underline{\text { Signature }}$

Human

Macaque

Chimpanzee

Marmoset

Bear

Panda

Mouse

Rat

Cow

Dog

Rabbit
VGERGAQLSGGQKQ

VGERGAQLSGGQKQ

VGERGAQLSGGQKQ

VGERGAQLSGGQKQ

VGDRGAQLSGGQKQ

VGDRGAQLSGGQKQ

VGDRGAQLSGGQKQ

VGDRGAQLSGGQKQ

VGERGAQLSGGQKQ

VGERGAQLSGGQKQ

VGERGAQLSGGQKQ
Human

Macaque

Chimpanzee

Marmoset

Bear

Panda

Mouse

Rat

Cow

Dog

Rabbit
Signature

TLPHKYETRVGDKGTQLSGGQKQ TLPHKYETRVGDKGSQLSGGQKQ TLPHKYETRVGDKGTQLSGGQKQ TLPHKYKTKVGDKGTQLSGGQKQ TLPYKYETRVGDKGTQLSGGQKQ TLPYKYETRVGDKGTQLSGGQKQ TLPQKYNTRVGDKGTQLSGGQKQ TLPQKYETRVGDKGTQLSGGQKQ TLPHKYETRVGDKGTQLSGGQKQ TLPHKYETRVGDKGTQLSGGQNK TLPHKYETRVGDKGTQLSGGQKQ
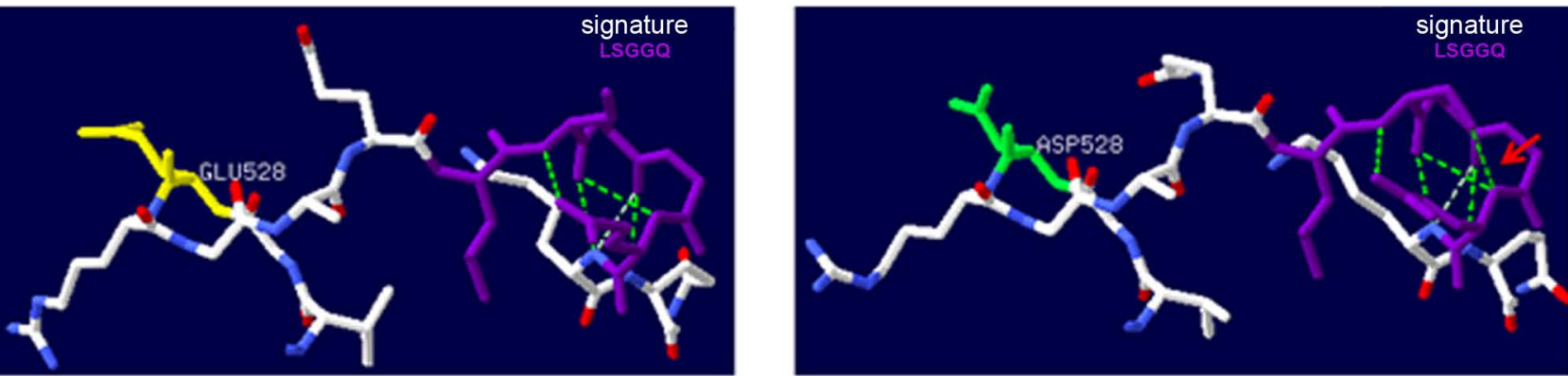

C
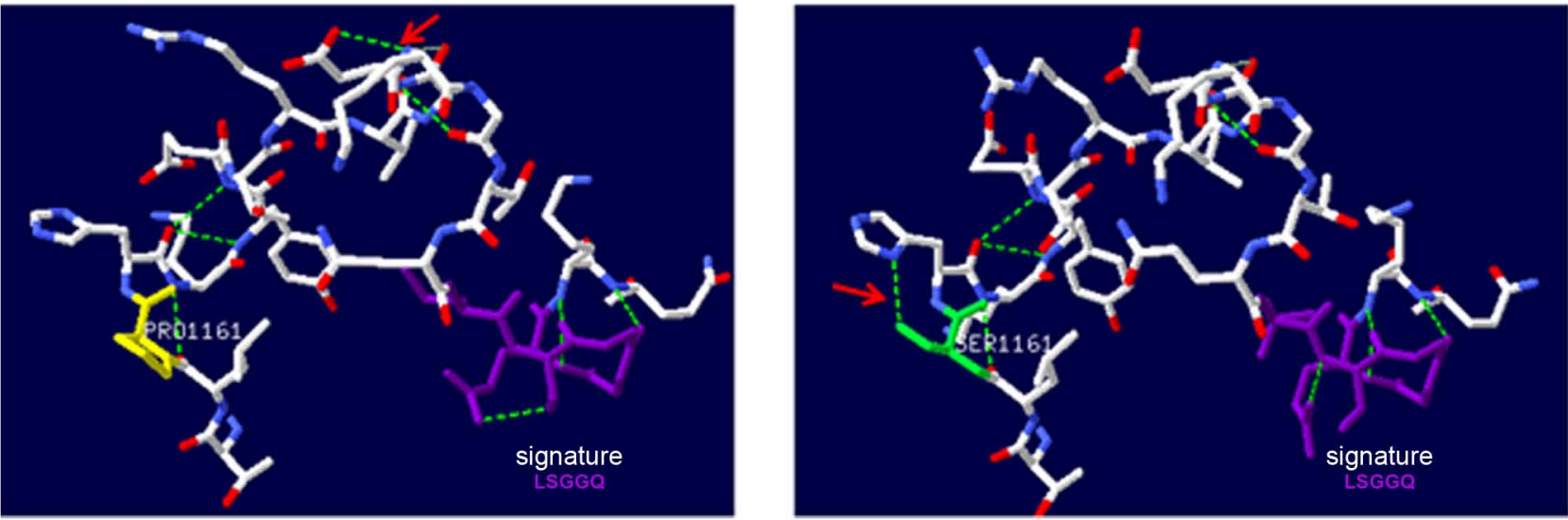

Figure 1 


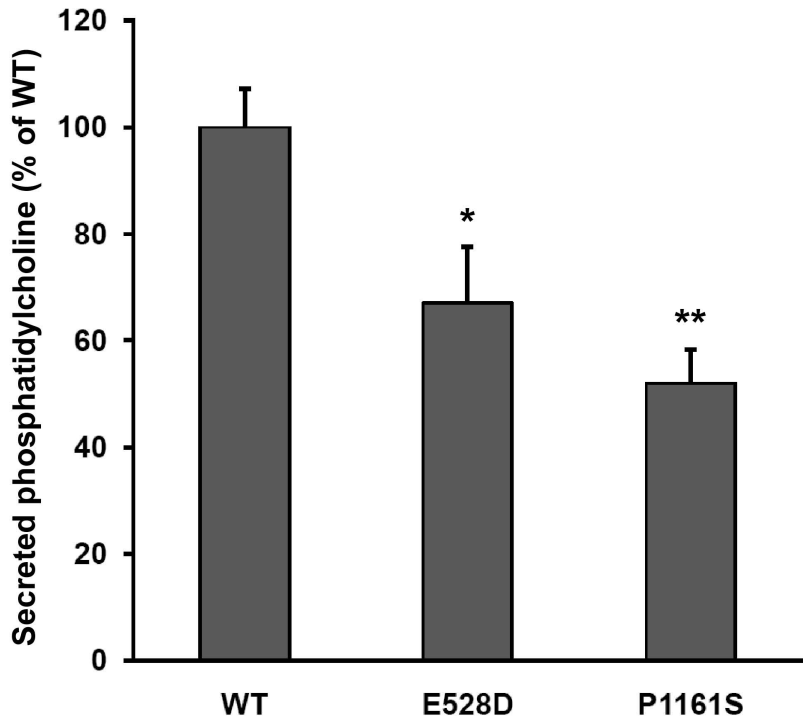

Figure 3 